\title{
Nitrogen sources and trace elements influence Laccase and peroxidase enzymes activity of Grammothele fuligo
}

\author{
Radha Chauhan ${ }^{1}$ (D)
}

Received: 25 April 2019 / Revised: 19 July 2019 / Accepted: 22 July 2019 / Published online: 6 August 2019

(c) The Author(s) 2019

\begin{abstract}
The effect of different organic, inorganic nitrogen sources and trace elements on growth and ligninolytic enzymes production by Grammothele fuligo has been investigated. Amongst all the nitrogen compounds used, the most favourable for growth was ammonium oxalate. It showed maximum Lignin Peroxidase activity $(80.6 \mathrm{IU} / \mathrm{mL})$ with ammonium chloride. The optimum Manganese Peroxidase activity $(4.13 \mathrm{IU} / \mathrm{mL})$ was observed with ammonium acetate. DL-alanine served as the best organic nitrogen source for the growth. The highest $\mathrm{MnP}(36.7 \mathrm{IU} / \mathrm{mL})$ and laccase $(3921.5 \mathrm{IU} / \mathrm{mL})$ activities were revealed in medium supplemented by DL-tryptophan. However, their positive effects on enzyme accumulation were due to a higher biomass production. The higher concentrations of trace elements were found to be fungistatic for its growth viz. $\mathrm{B}, \mathrm{Co}, \mathrm{Cu}$, $\mathrm{Fe}(400 \mathrm{ppm})$ and Co $(100 \mathrm{ppm})$. It exhibited maximum LiP activity $(456.9 \mathrm{IU} / \mathrm{mL})$ with $10^{-3} \mathrm{ppm} \mathrm{Fe}$ and MnP activity $(3.30 \mathrm{IU} / \mathrm{mL})$ with $10^{-6} \mathrm{ppm} \mathrm{B}$ and $10^{-3} \mathrm{ppm} \mathrm{Ca}$. The maximum laccase activity $(653.5 \mathrm{IU} / \mathrm{mL})$ was observed with $10^{-6}$ $\mathrm{ppm} \mathrm{Cu}$. This is the first report on nitrogen sources and trace elements effect on ligninolytic enzymes production of Grammothele. The results will facilitate research to understand the nature of the fungus and to increase its enzymes production under controlled conditions.
\end{abstract}

Keywords Ligninolytic enzymes $\cdot$ Nitrogen sources $\cdot$ Trace elements

\section{Introduction}

Many studies have proved that the nature and composition of culture medium regulate ligninolytic enzymes production by white rot fungi (Abdel-Azeem and Salem 2012). It has been concluded that the differential enzyme production is highly dependent on conditions or strains used (Tekere et al. 2001). Many white rot fungi produce an extracellular laccase under commonly adopted ligninolytic conditions. Studies have been conducted to select new species of white rot fungi for their overproduction to be used at large scale for industrial use such as in detergents, food, feed, pharmaceutical and biofuel (Bonugli-Santosa et al. 2010; Mtui 2012). Nitrogen sources appear to be another powerful factor affecting ligninolytic enzyme production of white rot fungi (Kenkebashvili et al. 2012; Mikiashvili et al. 2005).

Radha Chauhan

radhachauhann@gmail.com

1 Department of Botany, Panjab University, Sector-14, Chandigarh 160014, India
Many white-rot fungi exhibit significant effect of essential heavy metals such as $\mathrm{Cu}, \mathrm{Cd}, \mathrm{Mn}$ or $\mathrm{Zn}$ on their growth, reproduction and other metabolic functions (Chiu et al. 1998; Gabriel et al. 1996). The metals necessary for fungal growth include copper, iron, manganese, molybdenum, zinc, and nickel. Non-essential metals commonly include chromium, cadmium, lead, mercury and silver (Gadd 1993). The essential metals are relatively less toxic than heavy metals and increase the growth rate of fungi when present at low concentrations (Falih 1997, 1998). It seems that low concentrations of essential heavy metals are necessary for the development of the ligninolytic enzyme system (Périé and Gold 1991; Perez and Jeffries 1992; Singhal and Rathore 2001). The ability of many fungi to accumulate metals can be used for biotechnological applications in removal of heavy metal ions from polluted water, degradation of xenobiotic compounds (Baldrian 2003), bio-monitoring of atmosphere pollution (Baldrian et al. 1999; Gabriel et al. 1996). Grammothele fuligo (Berk. \& Broome) Ryvarden (the test fungus) is a wood rotting resupinate Agaricomycete growing on the petioles of Livistona chinensis (Jacquin) R. Brown. Since 
this fungus is cosmopolitan, however, still it has not been exploited for its ligninolytic enzymes applications in various industries e.g. pulp industry, paper industry etc. therefore it has been selected for the present studies. The aim of this study was to evaluate the significant effect of various nitrogen sources and trace elements for oxidative enzyme production by this fungus since such studies are a pre-requisite for commercial exploitation of these fungi for lignocellulolytic enzymes and organic acid production and no such studies have been conducted on it.

\section{Materials and methods}

\section{Microorganism and culture conditions}

Grammothele fuligo was maintained on $2 \%$ malt extract agar slants at $4{ }^{\circ} \mathrm{C}$ in the culture collection of Mycology and Plant Pathology Laboratory, Panjab University, Chandigarh. Glucose-peptone medium was used as the basal medium for the growth of the fungus. The carbon compound supporting optimum growth of this fungus determined in the previous experiment was incorporated in the selected basal media i.e. $10 \mathrm{~g} \mathrm{D}(+)$ Glucose (Prasher and Chauhan 2013) and other microelements (per liter) i.e. $1.0 \mathrm{~g} \mathrm{KH}_{2} \mathrm{PO}_{4}, 0.5 \mathrm{~g}$ $\mathrm{MgSO}_{4} .7 \mathrm{H}_{2} \mathrm{O}$ were added. $25 \mathrm{ml}$ of the basal media were apportioned in each $100 \mathrm{ml}$ sterilized Erlenmeyer conical flask aseptically. Each flask was seeded with inoculum having mycelial load of $2.5 \mathrm{mg}$ (by growing the mycelium for 4 days old culture in optimal basal medium under optimum conditions) and incubated at optimum temperatures of $24{ }^{\circ} \mathrm{C}$. After 12 days of incubation, found to be optimum days for its growth (Prasher and Chauhan 2013), the mycelia were separated by filtration and dried to constant weight at $45-50{ }^{\circ} \mathrm{C}$, while culture filtrates were used to measure the enzyme activity. Three replicates were kept in each variable in each experiment along with the control. At the end of each experiment, the mycelia were harvested through preweighed Whatman filter paper No. 1 and dried at $45^{\circ} \mathrm{C}$ in a hot air oven and their dry weights were measured using an electronic balance (Sartorius Analytical BL 210S).

\section{Effect of inorganic and organic nitrogen sources}

The different inorganic and organic nitrogen compounds were added in amounts equivalent to that of original nitrogen compound ( $2 \mathrm{~g} / \mathrm{l}$ of peptone in Glucose peptone medium, as peptone is a complex nitrogen compound) in the basal medium. The medium was adjusted to $\mathrm{pH} 7.0$ before sterilization. The basal medium without nitrogen source was used as control.

\section{Effect of trace elements}

The effects of different trace elements (B, Ca, Co, Cu, Fe, $\mathrm{Mn}, \mathrm{Mo}$ and $\mathrm{Zn})$ at different concentrations $\left(10^{-6}-400 \mathrm{ppm}\right)$ were evaluated on mycelial biomass and ligninolytic enzymes production at $24{ }^{\circ} \mathrm{C}, \mathrm{pH}-7.0$ with glucose used as carbon source and ammonium chloride acid as nitrogen source, after 12-days of incubation. However, prior to that the trace element contaminants from all the glassware were removed by chelation with disodium salt of EDTA $(0.1 \%$ w/v aq. solution). The salts used for trace elements were: $\mathrm{FeSO}_{4} .7 \mathrm{H}_{2} \mathrm{O}, \mathrm{ZnSO}_{4} .7 \mathrm{H}_{2} \mathrm{O}, \mathrm{MnCl}_{2} .7 \mathrm{H}_{2} \mathrm{O}, \mathrm{CaCl}_{2} .2 \mathrm{H}_{2} \mathrm{O}$, $\mathrm{CoCl}_{2} \cdot 6 \mathrm{H}_{2} \mathrm{O}, \mathrm{CuSO}_{4} \cdot 5 \mathrm{H}_{2} \mathrm{O},\left(\mathrm{NH}_{4}\right)_{6} \mathrm{Mo}_{7} \mathrm{O}_{24} \cdot 4 \mathrm{H}_{2} \mathrm{O}$ and $\mathrm{H}_{3} \mathrm{BO}_{3}$. The basal medium without added trace elements was served as control. The basal media supplemented with 7 trace elements and omitting one of the elements at a time were designated by zero concentration of the element.

\section{Enzyme assays}

Laccase activity: It was determined using the method of Coll et al. (1993). The reaction mixture was prepared by mixing $0.5 \mathrm{ml}$ of distilled water, $1 \mathrm{ml}$ of $50 \mathrm{mM}$ sodium acetate buffer ( $\mathrm{pH} 4.5$ ), $0.5 \mathrm{ml}$ of $46 \mathrm{mM}$ guaiacol and $0.5 \mathrm{ml}$ of culture filtrate. The activity of the enzyme was measured by taking the optical density of the reaction mixture at $440 \mathrm{~nm}$ on Shimadzu UV visible Spectrophotometer 1800 up to $90 \mathrm{~s}$ with $30 \mathrm{~s}$ of time interval.

Manganese peroxidase activity: It was assayed by following the method of Atalla et al. (2010), whereby guaiacol was used as a substrate. The reaction mixture contained $300 \mu \mathrm{l}$ of $0.5 \mathrm{M}$ sodium succinate buffer ( $\mathrm{pH}-4.5), 300 \mu$ l guaiacol $(4 \mathrm{mM}), 600 \mu \mathrm{MnSO}_{4}(1 \mathrm{mM}), 300 \mu \mathrm{l}$ culture filtrate and $1200 \mu \mathrm{l}$ distilled water. It was then incubated at $30^{\circ} \mathrm{C}$ for $2 \mathrm{~min}$ and the reaction was initiated by addition of $300 \mu \mathrm{l}$ of $\mathrm{H}_{2} \mathrm{O}_{2}(1 \mathrm{mM})$. The absorbance of the solution due to oxidation of guaiacol $\left(\varepsilon_{465}=12,100 \mathrm{M}^{-1} \mathrm{~cm}^{-1}\right)$ was measured at $465 \mathrm{~nm}$ on Shimadzu UV visible Spectrophotometer 1800 in $1 \mathrm{~min}$ intervals after addition of hydrogen peroxide.

Lignin peroxidase activity: It was measured using the method of Atalla et al. (2010). The reaction mixture contained $600 \mu \mathrm{l}$ of $0.3 \mathrm{M}$ citrate/0.4 M phosphate buffer (pH-4.5), $300 \mu \mathrm{l}$ of $8 \mathrm{mM}$ veratryl alcohol, $1890 \mu \mathrm{l}$ distilled water and $60 \mu \mathrm{l}$ of culture filtrate. The reaction mixture was then incubated at $30{ }^{\circ} \mathrm{C}$ for $2 \mathrm{~min}$. The reaction was initiated by addition of $150 \mu \mathrm{l}$ of $\mathrm{H}_{2} \mathrm{O}_{2}(5 \mathrm{mM})$. The absorbance of the solution was measured immediately in $1 \mathrm{~min}$ interval after addition of $\mathrm{H}_{2} \mathrm{O}_{2}$ at $310 \mathrm{~nm}$ on Shimadzu UV Spectrophotometer 1800. One unit of Lac, $\mathrm{MnP}$, and peroxidase activity was defined as an amount of enzyme that transformed $1 \mu \mathrm{mol}$ substrate per minute. 


\section{Statistical analyses}

All the experiments were performed in triplicates. The means of three replicate values for all data in the experiments obtained were tested in a one way ANOVA at $P=0.05$ using PASW Statistics 18 software and Tukey's test was used to evaluate differences between treatments.

\section{Results and discussion}

\section{Effect of inorganic and organic nitrogen sources}

Grammothele fuligo showed maximum average mycelial dry weight with ammonium oxalate $(65.0 \pm 1.68 \mathrm{mg} / 25 \mathrm{ml})$ followed by ammonium chloride, ammonium phosphate and ammonium sulphate whereas it exhibited least growth with potassium nitrate $(32.1 \pm 0.49 \mathrm{mg} / 25 \mathrm{ml})$ and sodium nitrate $(26.5 \pm 1.81 \mathrm{mg} / 25 \mathrm{ml})$ (Table 1). In case of organic nitrogen sources, it attained moderate growth with DL-alanine $(28.8 \pm 0.30 \mathrm{mg} / 25 \mathrm{ml})$ followed by L-glutamic acid, DLthreonine, DL-serine $\mathrm{HCl}$ and L-asparagine. It showed nil growth with L-arginine $\mathrm{HCl}$, di-hydroxy phenyl alanine, hydroxy-proline and L-tyrosine.

It showed poor growth with L-cysteine $\mathrm{HCl}$ $(10.7 \pm 0.05 \mathrm{mg} / 25 \mathrm{ml})$, L-cystine $(10.7 \pm 0.20 \mathrm{mg} / 25 \mathrm{ml})$ and L-proline $(7.0 \pm 0.15 \mathrm{mg} / 25 \mathrm{ml})$ (Table 2). It exhibited activity of LiP in medium containing ammonium chloride, ammonium sulphate $(80.6 \mathrm{IU} / \mathrm{mL})$ and it did not show LiP activity with any free amino acid. The maximum Laccase and $\mathrm{MnP}$ activity was observed to be $3921.5 \mathrm{IU} / \mathrm{mL}$ and 36.7 IU/mL, respectively, with DL-tryptophan. The highest MnP activity was observed with ammonium acetate,

Table 1 Growth (average mycelial dry wt.) and ligninolytic enzymes production of G. fuligo with different inorganic nitrogen compounds at $24{ }^{\circ} \mathrm{C}$ and $\mathrm{pH} 7.0$ after 12 days of incubation

\begin{tabular}{llll}
\hline Inorganic nitrogen source & $\begin{array}{l}\text { Average mycelial dry } \\
\text { wt. }(\mathrm{mg} / 25 \mathrm{ml})\end{array}$ & \multicolumn{2}{l}{$\begin{array}{l}\text { Enzyme activ- } \\
\text { ity (IU/mL) }\end{array}$} \\
\cline { 3 - 4 } & & $\mathrm{LiP}$ & $\mathrm{MnP}$ \\
\hline Control & $47.5 \pm 0.94$ & 107.5 & 5.37 \\
Ammonium acetate & $49.1 \pm 0.65$ & $\mathrm{ND}$ & 4.13 \\
Ammonium chloride & $61.7 \pm 0.72$ & 80.6 & $\mathrm{ND}$ \\
Ammonium nitrate & $48.9 \pm 0.69$ & $\mathrm{ND}$ & $\mathrm{ND}$ \\
Ammonium oxalate & $65.0 \pm 1.68$ & $\mathrm{ND}$ & $\mathrm{ND}$ \\
Ammonium phosphate & $58.4 \pm 1.26$ & $\mathrm{ND}$ & $\mathrm{ND}$ \\
Ammonium sulphate & $58.1 \pm 1.08$ & 80.6 & $\mathrm{ND}$ \\
Potassium nitrate & $32.1 \pm 0.49$ & $\mathrm{ND}$ & $\mathrm{ND}$ \\
Sodium nitrate & $26.5 \pm 1.81$ & $\mathrm{ND}$ & $\mathrm{ND}$ \\
Sodium nitrite & $2.5 \pm 0.00$ & $\mathrm{ND}$ & $\mathrm{ND}$ \\
\hline
\end{tabular}

$N D$ not detected
Table 2 Growth (average mycelial dry wt.) and ligninolytic enzymes production of $G$. fuligo with different organic nitrogen compounds at $24{ }^{\circ} \mathrm{C}$ and $\mathrm{pH} 7.0$ after 12 days of incubation

\begin{tabular}{lrll}
\hline Organic nitrogen source & $\begin{array}{l}\text { Average mycelial dry } \\
\text { wt. }(\mathrm{mg} / 25 \mathrm{ml})\end{array}$ & $\begin{array}{l}\text { Enzyme activity } \\
(\mathrm{IU} / \mathrm{mL})\end{array}$ \\
\cline { 3 - 4 } & & $\mathrm{MnP}$ & Lacc. \\
\hline Control & $7.7 \pm 0.20$ & 2.06 & $\mathrm{ND}$ \\
L- $\alpha$ amino-n butyric acid & $8.8 \pm 0.20$ & $\mathrm{ND}$ & $\mathrm{ND}$ \\
DL-Alanine & $28.8 \pm 0.30$ & $\mathrm{ND}$ & $\mathrm{ND}$ \\
L-Arginine HCl & $2.5 \pm 0.00$ & $\mathrm{ND}$ & $\mathrm{ND}$ \\
L-Asparagine & $17.0 \pm 0.15$ & $\mathrm{ND}$ & $\mathrm{ND}$ \\
DL-Aspartic acid & $13.9 \pm 0.05$ & $\mathrm{ND}$ & $\mathrm{ND}$ \\
L-Cysteine HCl & $10.7 \pm 0.05$ & 10.3 & $\mathrm{ND}$ \\
L-Cystine & $10.7 \pm 0.20$ & $\mathrm{ND}$ & 1176.4 \\
Dihydroxy phenylalanine & $2.5 \pm 0.00$ & $\mathrm{ND}$ & $\mathrm{ND}$ \\
L-Glutamic acid & $20.5 \pm 0.45$ & $\mathrm{ND}$ & 1176.4 \\
Glycine & $10.8 \pm 0.20$ & 1.65 & 784.3 \\
L-Histidine HCl & $10.0 \pm 0.25$ & $\mathrm{ND}$ & $\mathrm{ND}$ \\
Hydroxy-proline & $2.5 \pm 0.00$ & $\mathrm{ND}$ & $\mathrm{ND}$ \\
L-Leucine & $6.4 \pm 0.10$ & 4.95 & $\mathrm{ND}$ \\
Lysine HCl & $3.4 \pm 0.10$ & $\mathrm{ND}$ & $\mathrm{ND}$ \\
DL-Methionine & $4.0 \pm 0.10$ & $\mathrm{ND}$ & $\mathrm{ND}$ \\
L-Ornithine HCl & $6.1 \pm 0.15$ & 2.47 & $\mathrm{ND}$ \\
Phenyl alanine & $5.8 \pm 0.25$ & $\mathrm{ND}$ & $\mathrm{ND}$ \\
L-Proline & $7.0 \pm 0.15$ & $\mathrm{ND}$ & $\mathrm{ND}$ \\
DL-Serine HCl & $19.2 \pm 0.10$ & 1.65 & $\mathrm{ND}$ \\
DL-Threonine & $20.2 \pm 0.40$ & 1.65 & $\mathrm{ND}$ \\
DL-Tryptophan & $14.9 \pm 0.15$ & 36.7 & 3921.5 \\
L-Tyrosine & $2.5 \pm 0.00$ & $\mathrm{ND}$ & $\mathrm{ND}$ \\
DL-Valine & $10.8 \pm 0.05$ & $\mathrm{ND}$ & $\mathrm{ND}$ \\
\hline & & & \\
& & & \\
& & & \\
& & &
\end{tabular}

DL-tryptophan followed by L-cysteine $\mathrm{HCl}$ i.e. $4.13 \mathrm{IU} /$ $\mathrm{mL}, 36.7 \mathrm{IU} / \mathrm{mL}$ and $10.3 \mathrm{IU} / \mathrm{mL}$, respectively.

Many fungal isolates exhibited good to moderate growth with ammonium salts and nitrate salts as have been reported in various reports e.g. Panellus stipticus (Prasher et al. 2014) and Dictyoarthrinium synnematicum (Prasher and Chauhan 2015). In utilizing nitrate sources of nitrogen the fungus resembles other fungi like Fusarium oxysporum, Phoma nebulosa and Botryodiplodia theobromae (Dandge 2012), Trichoderma viride and Beauveria bassiana (Mehta et al. 2012). The findings are in conformity with the studies conducted by various workers where L-proline was reported as poor nitrogen source for growth of various fungi viz. Tetracladium marchalianum and Tetrachaetum elegans (Bisht 2013). However, the present findings are contrary to earlier reports where L-cysteine $\mathrm{HCl}$ promoted good to moderate growth of some fungi e.g. Flagellospora penicilloides and Pestalotiopsis submerses (Bisht 2013) and L-cystine in Fomitiporia sp. F6 and Fp strains (Terashima 2013). 
L-tyrosine was found to inhibit the growth of the fungus which is contrary to the earlier reports where moderate growth has been reported with L-tyrosine e.g. Curvularia senegalensis, Curvularia prasadii and Phoma vulgaris (Dandge 2012). Stajic et al. (2006) reported the highest Laccase activity with ammonium sulphate as nitrogen supplement and least activity with potassium nitrate in Pleurotus eryngii and Pleurotus ostreatus strain 493 while Pleurotus ostreatus strain 494 exhibited highest enzyme activity with peptone and ammonium chloride. In Cerrena unicolor IBB 62 (Elisashvili et al. 2001), the highest Laccase activity was observed in medium supplemented with ammonium sulphate whereas, in Pleurotus ostreatus (Stajic et al. 2006), Trametes gallica (Levin et al. 2010), Coriolopsis gallica (Kenkebashvili et al. 2012), Fibrodontia sp. RCK783S (Vaithanomsat et al. 2013) and Neolentinus kauffmanii (Johnsy and Kaviyarasan 2014), it was found to be maximum with peptone. However, in case of $G$. fuligo, Laccase activity was not observed with any inorganic nitrogen source. Kenkebashvili et al. (2012) observed maximum MnP accumulation by Coriolopsis gallica in medium containing peptone as efficient nitrogen source. Similar results were also observed with Cerrena unicolor IBB 62 (Elisashvili et al. 2001) and Pleurotus eryngii, Pleurotus pulmonarius and Pleurotus sajor-caju (Martínez et al. 1996). Glutamic acid (free amino acid) is reported to be the best nitrogen source for the production of Laccase and $\mathrm{MnP}$ by fungi like Coriolus versicolor and Trametes trogii (Levin et al. 2010).

Contradictory results have been reported for the effect of concentration and source of nitrogen on ligninolytic enzymes (Galhaup et al. 2002). It has been reported that the production of ligninolytic enzymes i.e. Laccase, MnP and LiP depends not only on the species of fungi but also on the culture conditions, carbon and nitrogen sources and their concentrations (Mikiashvili et al. 2005; Stajic et al. 2006).

\section{Effect of trace elements}

Optimum concentrations of trace elements required for optimum biomass production of $G$. fuligo were found to be: $\mathrm{B}, \mathrm{Cu}, \mathrm{Fe}\left(10^{-3} \mathrm{ppm}\right)$; $\mathrm{Ca}(100 \mathrm{ppm})$; Co, Mn $\left(0-10^{-6}\right.$ ppm); Mo $\left(10^{-5} \mathrm{ppm}\right)$ and $\mathrm{Zn}\left(10^{-4} \mathrm{ppm}\right)$. Among these trace elements, it showed maximum biomass production i.e. $12.8 \pm 0.74 \mathrm{mg} / 25 \mathrm{ml}$ with $\mathrm{Fe}$ at $10^{-3} \mathrm{ppm}$.

However, the higher concentrations of these trace elements were found to be fungistatic for the growth of $G$. fuligo viz. $400 \mathrm{ppm}$ of $\mathrm{B}, \mathrm{Co}, \mathrm{Cu}, \mathrm{Fe}$ and $100 \mathrm{ppm}$ of $\mathrm{Co}$. It did not show any Laccase activity with $\mathrm{Ca}, \mathrm{Mn}$ and $\mathrm{Zn}$; and Manganese peroxidase activity with $\mathrm{Co}$ and $\mathrm{Fe}$. It showed variability in ligninolytic enzyme activities with different concentrations of different trace elements (Table 3, 4, 5, 6, 7, 8, 9 and 10). It exhibited maximum LiP activity i.e. $456.9 \mathrm{IU} / \mathrm{mL}$ with $10^{-3} \mathrm{ppm}$ conc. of Fe and MnP activity up
Table 3 Growth (average mycelial dry wt.) and ligninolytic enzymes production of $G$. fuligo with different concentrations of Boron, at $24{ }^{\circ} \mathrm{C}$ and $\mathrm{pH} 7.0$ after 12 days of incubation

\begin{tabular}{lclll}
\hline Boron conc. (ppm) & $\begin{array}{l}\text { Average mycelial } \\
\text { dry wt. }(\mathrm{mg} / 25 \mathrm{ml})\end{array}$ & \multicolumn{2}{l}{$\begin{array}{l}\text { Enzyme activity (IU/ } \\
\mathrm{mL})\end{array}$} \\
\cline { 3 - 5 } & & $\mathrm{LiP}$ & $\mathrm{MnP}$ & Lacc. \\
\hline Control & $9.03 \pm 0.03$ & 241.9 & 2.47 & 522.8 \\
0 & $8.20 \pm 0.08$ & 241.9 & 3.30 & 522.8 \\
$10^{-6}$ & $9.16 \pm 0.16$ & 295.6 & 3.30 & 392.1 \\
$10^{-5}$ & $9.83 \pm 0.03$ & 241.9 & 2.89 & 261.4 \\
$10^{-4}$ & $10.63 \pm 0.03$ & 268.8 & 2.47 & 261.4 \\
$10^{-3}$ & $12.56 \pm 0.26$ & 215.0 & 2.06 & 653.5 \\
$10^{-2}$ & $10.96 \pm 0.29$ & 215.0 & 2.06 & 261.4 \\
$10^{-1}$ & $9.56 \pm 0.03$ & 188.1 & 2.89 & 784.3 \\
1.0 & $9.13 \pm 0.08$ & 188.1 & 2.06 & 653.5 \\
10 & $8.46 \pm 0.16$ & 161.2 & 1.65 & 653.5 \\
100 & $6.70 \pm 0.03$ & 161.2 & 2.06 & 915.0 \\
400 & $2.5 \pm 0.00$ & ND & ND & ND \\
\hline
\end{tabular}

Table 4 Growth (average mycelial dry wt.) and ligninolytic enzymes production of $G$. fuligo with different concentrations of Calcium, at $24^{\circ} \mathrm{C}$ and $\mathrm{pH} 7.0$ after 12 days of incubation

\begin{tabular}{lcrc}
\hline $\begin{array}{l}\text { Calcium conc. } \\
(\mathrm{ppm})\end{array}$ & $\begin{array}{l}\text { Average mycelial dry wt. } \\
(\mathrm{mg} / 25 \mathrm{ml})\end{array}$ & \multicolumn{2}{l}{$\begin{array}{l}\text { Enzyme activity (IU/ } \\
\mathrm{mL})\end{array}$} \\
\cline { 3 - 4 } & & $\mathrm{LiP}$ & $\mathrm{MnP}$ \\
\hline Control & $9.03 \pm 0.03$ & 241.9 & 2.47 \\
0 & $4.23 \pm 0.08$ & 53.7 & 1.23 \\
$10^{-6}$ & $7.16 \pm 0.03$ & 80.6 & 0.82 \\
$10^{-5}$ & $8.43 \pm 0.03$ & 80.6 & 0.82 \\
$10^{-4}$ & $8.73 \pm 0.08$ & 107.5 & 2.06 \\
$10^{-3}$ & $9.36 \pm 0.06$ & 26.8 & 3.30 \\
$10^{-2}$ & $9.56 \pm 0.08$ & 26.8 & 1.65 \\
$10^{-1}$ & $9.83 \pm 0.03$ & 26.8 & 1.23 \\
1.0 & $9.93 \pm 0.03$ & 26.8 & 1.23 \\
10 & $10.53 \pm 0.06$ & 53.7 & 0.82 \\
100 & $10.76 \pm 0.08$ & 53.7 & 1.23 \\
400 & $10.23 \pm 0.06$ & 53.7 & 1.23 \\
\hline
\end{tabular}

to $3.30 \mathrm{IU} / \mathrm{mL}$ with $10^{-6} \mathrm{ppm} \mathrm{B}$ and $10^{-3} \mathrm{ppm} \mathrm{Ca}$. The maximum activity of laccase was observed with $10^{-6} \mathrm{ppm} \mathrm{Cu}$ i.e. $653.5 \mathrm{IU} / \mathrm{mL}$. It showed all the three ligninolytic enzymes activity at different concentration of Boron (Table 3), Copper (Table 6) and Molybdenum (Table 9); only LiP and MnP activity at different concentrations of Calcium (Table 4), Manganese (Table 8) and Zinc (Table 10) whereas only LiP and Laccase activity were shown with different concentrations of Cobalt (Table 5) and Iron (Table 7).

In requiring Boron, G. fuligo (Table 3) resembles other fungi like Alternaria burnsii (Sankhla et al. 1970), 
Table 5 Growth (average mycelial dry wt.) and ligninolytic enzymes production of $G$. fuligo with different concentrations of Cobalt, at $24{ }^{\circ} \mathrm{C}$ and $\mathrm{pH} 7.0$ after 12 days of incubation

\begin{tabular}{lcll}
\hline Cobalt conc. (ppm) & $\begin{array}{l}\text { Average mycelial dry } \\
\text { wt. }(\mathrm{mg} / 25 \mathrm{ml})\end{array}$ & \multicolumn{2}{l}{$\begin{array}{l}\text { Enzyme activity } \\
(\mathrm{IU} / \mathrm{mL})\end{array}$} \\
\cline { 3 - 4 } & & LiP & Lacc. \\
\hline Control & $9.03 \pm 0.03$ & 241.9 & 522.8 \\
0 & $14.03 \pm 0.06$ & 268.8 & 653.5 \\
$10^{-6}$ & $10.56 \pm 0.03$ & 215.0 & 392.1 \\
$10^{-5}$ & $9.70 \pm 0.05$ & 241.9 & 392.1 \\
$10^{-4}$ & $9.23 \pm 0.03$ & 241.9 & 522.8 \\
$10^{-3}$ & $9.03 \pm 0.03$ & 215.0 & 261.4 \\
$10^{-2}$ & $9.03 \pm 0.03$ & 188.1 & 261.4 \\
$10^{-1}$ & $8.83 \pm 0.03$ & 134.4 & 130.7 \\
1.0 & $8.53 \pm 0.08$ & 107.5 & ND \\
10 & $5.56 \pm 0.12$ & 107.5 & ND \\
100 & $2.5 \pm 0.00$ & ND & ND \\
400 & $2.5 \pm 0.00$ & ND & ND \\
\hline
\end{tabular}

Table 6 Growth (average mycelial dry wt.) and ligninolytic enzymes production of $G$. fuligo with different concentrations of Copper, at $24{ }^{\circ} \mathrm{C}$ and $\mathrm{pH} 7.0$ after 12 days of incubation

\begin{tabular}{lllll}
\hline $\begin{array}{l}\text { Copper conc. } \\
(\mathrm{ppm})\end{array}$ & $\begin{array}{l}\text { Average mycelial dry } \\
\text { wt. }(\mathrm{mg} / 25 \mathrm{ml})\end{array}$ & \multicolumn{3}{l}{ Enzyme activity (IU/mL) } \\
\cline { 3 - 5 } & & LiP & MnP & Lacc. \\
\hline Control & $9.03 \pm 0.03$ & 241.9 & 2.47 & 522.8 \\
0 & $7.40 \pm 0.17$ & 161.2 & 2.47 & 522.8 \\
$10^{-6}$ & $8.10 \pm 0.05$ & 107.5 & 1.65 & 653.5 \\
$10^{-5}$ & $8.46 \pm 0.03$ & 80.6 & 1.23 & 261.4 \\
$10^{-4}$ & $8.86 \pm 0.03$ & 134.4 & 0.82 & 261.4 \\
$10^{-3}$ & $10.9 \pm 0.17$ & 107.5 & 2.47 & 392.1 \\
$10^{-2}$ & $10.1 \pm 0.03$ & 134.4 & 2.06 & 261.4 \\
$10^{-1}$ & $8.83 \pm 0.03$ & 134.4 & 2.06 & 522.8 \\
1.0 & $8.40 \pm 0.05$ & 107.5 & 0.82 & 392.1 \\
10 & $7.26 \pm 0.03$ & 107.5 & ND & ND \\
100 & $5.76 \pm 0.03$ & 107.5 & ND & ND \\
400 & $2.5 \pm 0.00$ & ND & ND & ND \\
\hline
\end{tabular}

Saccharomyces cerevisiae (Bennett et al. 1999), where Boron is found to be beneficial for the growth. However, Bowen and Gauch (1966) reported the non-essentiality of boron for the growth of Saccharomyces cerevisiae, Aspergillus niger, Neurospora crassa and Penicillium chrysogenum.

In utilizing $\mathrm{Ca}$ for growth, G. fuligo (Table 4) resembles other fungi. The results are in accordance with other workers like Davis et al. (1928) who reported that Ca has stimulatory effect on fungal growth. Copper is required for the growth of many fungi (Dong and Yao 2005) and is also a known fungicide even in low concentrations. However, Grammothele
Table 7 Growth (average mycelial dry wt.) and ligninolytic enzymes production of $G$. fuligo with different concentrations of Iron, at $24{ }^{\circ} \mathrm{C}$ and $\mathrm{pH} 7.0$ after 12 days of incubation

\begin{tabular}{llll}
\hline Iron conc. (ppm) & $\begin{array}{l}\text { Average mycelial dry } \\
\text { wt. }(\mathrm{mg} / 25 \mathrm{ml})\end{array}$ & \multicolumn{2}{l}{$\begin{array}{l}\text { Enzyme activity } \\
(\mathrm{IU} / \mathrm{mL})\end{array}$} \\
\cline { 3 - 4 } & & $\mathrm{LiP}$ & Lacc. \\
\hline Control & $9.03 \pm 0.03$ & 241.9 & 522.8 \\
0 & $6.73 \pm 0.17$ & 161.2 & 130.7 \\
$10^{-6}$ & $7.30 \pm 0.15$ & 161.2 & 130.7 \\
$10^{-5}$ & $9.90 \pm 0.05$ & 268.8 & 261.4 \\
$10^{-4}$ & $10.1 \pm 0.03$ & 376.3 & 392.1 \\
$10^{-3}$ & $12.8 \pm 0.74$ & 456.9 & 392.1 \\
$10^{-2}$ & $9.16 \pm 0.08$ & 268.8 & 261.4 \\
$10^{-1}$ & $8.63 \pm 0.06$ & 241.9 & 261.4 \\
1.0 & $8.13 \pm 0.06$ & 188.1 & 261.4 \\
10 & $7.76 \pm 0.08$ & ND & ND \\
100 & $6.36 \pm 0.27$ & ND & ND \\
400 & $2.5 \pm 0.00$ & ND & ND \\
\hline
\end{tabular}

Table 8 Growth (average mycelial dry wt.) and ligninolytic enzymes production of $G$. fuligo with different concentrations of Manganese, at $24{ }^{\circ} \mathrm{C}$ and $\mathrm{pH} 7.0$ after 12 days of incubation

\begin{tabular}{lcll}
\hline $\begin{array}{l}\text { Manganese conc. } \\
(\mathrm{ppm})\end{array}$ & $\begin{array}{l}\text { Average mycelial dry wt. } \\
(\mathrm{mg} / 25 \mathrm{ml})\end{array}$ & $\begin{array}{l}\text { Enzyme activity } \\
(\mathrm{IU} / \mathrm{mL})\end{array}$ \\
\cline { 3 - 4 } & & $\mathrm{LiP}$ & $\mathrm{MnP}$ \\
\hline Control & $9.03 \pm 0.03$ & 241.9 & 2.47 \\
0 & $12.20 \pm 0.14$ & 80.6 & 1.23 \\
$10^{-6}$ & $11.66 \pm 0.06$ & 80.6 & 2.06 \\
$10^{-5}$ & $11.03 \pm 0.08$ & 26.8 & 1.23 \\
$10^{-4}$ & $10.80 \pm 0.03$ & 134.4 & 0.82 \\
$10^{-3}$ & $10.30 \pm 0.05$ & 161.2 & $\mathrm{ND}$ \\
$10^{-2}$ & $10.10 \pm 0.05$ & 188.1 & $\mathrm{ND}$ \\
$10^{-1}$ & $9.90 \pm 0.05$ & 107.5 & $\mathrm{ND}$ \\
1.0 & $9.63 \pm 0.12$ & 80.6 & $\mathrm{ND}$ \\
10 & $9.00 \pm 0.05$ & 26.8 & $\mathrm{ND}$ \\
100 & $8.26 \pm 0.26$ & $\mathrm{ND}$ & $\mathrm{ND}$ \\
400 & $5.93 \pm 0.12$ & $\mathrm{ND}$ & $\mathrm{ND}$ \\
\hline
\end{tabular}

fuligo showed optimum growth at very low concentrations $\left(10^{-3} \mathrm{ppm}\right)$.

The higher concentration of $\mathrm{Cu}$ was found to be fungistatic for the growth of G. fuligo. It showed variability in ligninolytic enzyme activities with different concentrations of $\mathrm{Cu}$.

The positive effect of Copper on the production of laccase has been exhibited in Pleurotus ostreatus (Baldrian and Gabriel 2002, Hou et al. 2004), Pleurotus pulmonarius (Tychanowicz et al. 2006) and Trametes versicolor (Lorenzo et al. 2006). 
Table 9 Growth (average mycelial dry wt.) and ligninolytic enzymes production of G. fuligo with different concentrations of Molybdenum, at $24{ }^{\circ} \mathrm{C}$ and $\mathrm{pH} 7.0$ after 12 days of incubation

\begin{tabular}{lclll}
\hline $\begin{array}{l}\text { Molybdenum } \\
\text { conc. }(\mathrm{ppm})\end{array}$ & $\begin{array}{l}\text { Average mycelial dry } \\
\text { wt. }(\mathrm{mg} / 25 \mathrm{ml})\end{array}$ & \multicolumn{3}{l}{ Enzyme activity (IU/mL) } \\
\cline { 3 - 5 } & & LiP & MnP & Lacc. \\
\hline Control & $9.03 \pm 0.03$ & 241.9 & 2.47 & 522.8 \\
0 & $9.43 \pm 0.08$ & 134.4 & 0.82 & 261.4 \\
$10^{-6}$ & $11.20 \pm 0.10$ & 188.1 & 0.82 & 522.8 \\
$10^{-5}$ & $13.83 \pm 0.49$ & 134.4 & 1.23 & 261.4 \\
$10^{-4}$ & $12.26 \pm 0.03$ & 107.5 & 1.65 & 261.4 \\
$10^{-3}$ & $12.06 \pm 0.06$ & 107.5 & 1.23 & 261.4 \\
$10^{-2}$ & $11.30 \pm 0.05$ & 134.4 & 1.23 & 130.7 \\
$10^{-1}$ & $11.13 \pm 0.03$ & 80.6 & 0.82 & 130.7 \\
1.0 & $10.43 \pm 0.18$ & 80.6 & 0.82 & ND \\
10 & $10.10 \pm 0.15$ & ND & ND & ND \\
100 & $7.90 \pm 0.10$ & ND & ND & ND \\
400 & $7.60 \pm 0.11$ & ND & ND & ND \\
\hline
\end{tabular}

Table 10 Growth (average mycelial dry wt.) and ligninolytic enzymes production of $G$. fuligo with different concentrations of Zinc, at $24{ }^{\circ} \mathrm{C}$ and $\mathrm{pH} 7.0$ after 12 days of incubation

\begin{tabular}{lcrc}
\hline Zinc conc. (ppm) & $\begin{array}{l}\text { Average mycelial dry } \\
\text { wt. }(\mathrm{mg} / 25 \mathrm{ml})\end{array}$ & \multicolumn{2}{c}{$\begin{array}{l}\text { Enzyme activity } \\
(\mathrm{IU} / \mathrm{mL})\end{array}$} \\
\cline { 3 - 4 } & & \multicolumn{1}{c}{$\mathrm{LiP}$} & $\mathrm{MnP}$ \\
\hline Control & $9.03 \pm 0.03$ & 241.9 & 2.47 \\
0 & $9.50 \pm 0.10$ & 80.6 & 1.23 \\
$10^{-6}$ & $10.70 \pm 0.11$ & 80.6 & 0.82 \\
$10^{-5}$ & $11.21 \pm 0.03$ & 53.7 & 1.65 \\
$10^{-4}$ & $11.93 \pm 0.23$ & 80.6 & 1.65 \\
$10^{-3}$ & $11.36 \pm 0.03$ & 80.6 & 1.23 \\
$10^{-2}$ & $11.10 \pm 0.10$ & 107.5 & 1.23 \\
$10^{-1}$ & $10.43 \pm 0.03$ & 134.4 & 0.82 \\
1.0 & $10.33 \pm 0.03$ & 134.4 & 0.82 \\
10 & $10.20 \pm 0.05$ & 295.6 & 0.82 \\
100 & $9.03 \pm 0.03$ & 241.9 & 2.47 \\
400 & $9.50 \pm 0.10$ & 80.6 & 1.23 \\
\hline
\end{tabular}

There are few reports in the literature which supports the requirement of Co for the growth of fungi e.g. Alternaria chartarum and Alternaria solani (Madan and Thind 1979) whereas G. fuligo showed little growth with Co at very low concentration. Grammothele fuligo showed optimum growth and production of LiP and Laccase activities at optimum concentration of $\mathrm{Fe}$. The results confirm the finding of many workers where it is shown to be required for growth and sporulation by many fungi like Aspergillus flavus (Cuero et al. 2003) and Yarrowia lipolytica (Anastassiadis et al. 2007). It has stimulatory effect on Laccase activity in Pleurotus ostreatus (Stajic et al. 2013), however, it is found to be inhibitory for Laccase production in case of Ganoderma lucidum (Murugesan et al. 2009) and Pleurotus pulmonarius (Stajic et al. 2013). Grammothele fuligo has also utilized Mn for producing ligninolytic enzymes and mycelial growth. In some fungi, $\mathrm{Mn}$ is shown to be required for synthesis of primary and secondary fungal metabolites e.g. Agrocybe aegerita (Sharma et al. 2004) and Cordyceps sinensis (Dong and Yao 2005). The positive effect of Mn on Laccase production has been exhibited in Agrocybe praecox and Stropharia coronilla (Steffen et al. 2002) and Trametes versicolor (Lorenzo et al. 2006), whereas Grammothele fuligo did not exhibit any Laccase activity with Mn. Grammothele fuligo exhibited $\mathrm{MnP}$ activity at low concentrations $\left(10^{-6}\right.$ to $10^{-4} \mathrm{ppm}$ ).

The growth of many fungi decreases in presence of Mo like, Phlebia radiata, Pleurotus pulmonarius and Physisporinus rivulosus (Kluczek-Turpeinen et al. 2014) while some species like Alternaria alternata, Aspergillus flavus and Cladosporium herbarum are tolerant to Mo (Hashem 1997). However, G. fuligo showed mycelial growth at all concentrations of Mo used in the experiment. Laccase activity has been reported to decrease in presence of Mo in G. fuligo, similar effects have been observed with Phlebia radiata, Pleurotus pulmonarius and Physisporinus rivulosus (Kluczek-Turpeinen et al. 2014). Grammothele fuligo resembles other fungi where zinc is reported to influence their growth like Cordyceps sinensis (Dong and Yao 2005), Pleurotus ostreatus (Baldrian et al. 2005) and Alternaria alternata S3S (Ezzouhri et al. 2009). However, there is a fungus which showed contrary results with Zinc where it inhibits the growth e.g. Dictyoarthrinium synnematicum (Prasher and Chauhan 2017). Grammothele fuligo did not show any Laccase activity with $\mathrm{Zn}$ at any concentration similar inhibitory effects have been observed in case of Pleurotus pulmonarius (Stajic et al. 2013), Ganoderma lucidum (Murugesan et al. 2009) and Dictyoarthrinium synnematicum (Prasher and Chauhan 2017). However, the stimulatory effect of $\mathrm{Zn}$ on Laccase activity has been exhibited in Pleurotus ostreatus (Stajic et al. 2013). Since, the tested fungus showed variability in production of laccase, Lip and MnP in relation to different concentrations of trace elements, it becomes necessary to know its ability to produce ligninolytic enzymes in different synthetic media. The results will facilitate research to understand the nature of the fungus and to increase its enzymes production under controlled conditions.

Acknowledgements The author acknowledges the Department of Science and Technology, Government of India, for the financial support in the form of fellowship under PURSE grant during the course of the study and also thankful to the Chairperson, Department of Botany, Panjab University, Chandigarh, for providing the facilities used during part of the experiments in this study. 
Open Access This article is distributed under the terms of the Creative Commons Attribution 4.0 International License (http://creativecommons .org/licenses/by/4.0/), which permits unrestricted use, distribution, and reproduction in any medium, provided you give appropriate credit to the original author(s) and the source, provide a link to the Creative Commons license, and indicate if changes were made.

\section{References}

Abdel-Azeem AM, Salem FM (2012) Biodiversity of laccase producing fungi in Egypt. Mycosphere 3:900-920

Anastassiadis S, Kamzolova SV, Morgunov IG, Rehm HJ (2007) Comparative study of the effect of iron on citrate-producing yeast growing on different substrates. In: Méndez-Vilas A (ed) Communicating Current Research and Educational Topics and Trends in Applied Microbiology, vol 1. Formatex, Spain, pp 308-314

Atalla MM, Zeinab HK, Eman RH, Amani AY, Abeer AAEA (2010) Screening of some marine-derived fungal isolates for lignin degrading enzymes (LDEs) production. Agric Biol J N Am 1:591-599

Baldrian P (2003) Interactions of heavy metals with white-rot fungi. Enzyme Microb Technol 32:78-91

Baldrian P, Gabriel J (2002) Copper and cadmium increase laccase activity in Pleurotus ostreatus. FEMS Microbiol Lett 206:69-74

Baldrian P, Gabriel J, Curdová E, Suchánek M, Rychlovský P (1999) Heavy and trace metals in wood-inhabiting fungi Fomitopsis pinicola, Ganoderma applanatum, Piptoporus betulinus and Stereum hirsutum from medium polluted sites in Czech Republic. Toxicol Environ Chem 71:475-483

Baldrian P, Valášková V, Merhautová V, Gabriel J (2005) Degradation of lignocellulose by Pleurotus ostreatus in the presence of copper, manganese, lead and zinc. Res Microbiol 156:670-676

Bennett A, Rowe RI, Soch N, Eckhert CD (1999) Boron stimulates yeast (Saccharomyces cerevisiae) growth. J Nutr 129:2236-2238

Bisht S (2013) Growth responses of aquatic hyphomycetes to different sources of carbon and nitrogen. J Appl Nat Sci 5:313-317

Bonugli-Santosa RC, Durrant LR, da Silva M, Sette LD (2010) Production of laccase, manganese peroxidase and lignin peroxidase by Brazilian marine-derived fungi. Enzyme Microb Technol 46:32-37

Bowen JE, Gauch HG (1966) Non-essentiality of boron in fungi and the nature of its toxicity. Plant Physiol 41:319-324

Chiu SW, Chan YH, Law SC, Cheung KT, Moore D (1998) Cadmium and manganese in contrast to calcium reduce yield and nutritional values of the edible mushroom Pleurotus pulmonarius. Mycol Res 102:449-457

Coll MP, Abalos JMF, Villanueva JR, Santamaria R, Perez P (1993) Purification and characterization of phenol oxidase (Laccase) from the lignin-degrading basidiomycete PM I (CECT 2971). Appl Environ Microbiol 59:2607-2613

Cuero R, Ouellet T, Yu J, Mogongwa N (2003) Metal ion enhancement of fungal growth, gene expression and aflatoxin synthesis in Aspergillus flavus: RT-PCR characterization. J Appl Microbiol 94:953-961

Dandge VS (2012) Effect of nitrogen sources on the growth of different species of Curvularia, Fusarium, Phoma and Botryodiplodia. J Exp Sci 3:24-27

Davis AR, Marloth RH, Bishop CJ (1928) The inorganic nutrition of the fungi I. Phytopathol 18:949

Dong CH, Yao YJ (2005) Nutritional requirements of mycelial growth of Cordyceps sinensis in submerged culture. J Appl Microbiol 99:483-492
Elisashvili V, Parlar H, Kachlishvili E, Chichua D, Kvesitadze G (2001) Lignocellulolytic activity of Basidiomycetes grown under submerged and solid-state fermentation on plant raw material (sawdust of grapevine cuttings). Adv Food Sci 23:117-123

Ezzouhri L, Castro E, Moya M, Espinola F, Lairini K (2009) Heavy metal tolerance of filamentous fungi isolated from polluted sites in Tangier, Morocco. Afr J Microbiol Res 3:35-48

Falih AM (1997) Influence of heavy-metals toxicity on the growth of Phanerochaete chrysosporium. Bioresour Technol 60:87-90

Falih AM (1998) Impact of heavy metals on cellulolytic activity of some soil fungi. Kuwait J Sci Eng 25:397-407

Gabriel J, Capelari M, Rychlovsky P, Krenzelok M, Zadrazil F (1996) Influence of cadmium on the growth of Agrocybe perfecta and two Pleurotus spp. and translocation from polluted substrate and soil to fruitbodies. Toxicol Environ Chem 56:141-146

Gadd GM (1993) Interactions of fungi with toxic metals. New Phytol $124: 25-60$

Galhaup C, Wagner H, Hinterstoisser B, Haltrich D (2002) Increased production of laccase by the wood-degrading basidiomycete Trametes pubescens. Enzyme Microb Technol 30:529-536

Hashem AR (1997) Effect of heavy metal ions on the mycelial growth of some fungi isolated from the soil of Al-Jubail Industry City, Saudi-Arabia. J King Saud Univ 9:119-124

Hou H, Zhou J, Wang J, Du C, Yan B (2004) Enhancement of laccase production by Pleurotus ostreatus and its use for the decolorization of anthraquinone dye. Process Biochem 39:1415-1419

Johnsy G, Kaviyarasan V (2014) Effect of physico-chemical parameters on ligninolytic enzyme production of an indigenous isolate of Neolentinus kauffmanii -under submerged culture condition. World J Pharm Sci 2:464-468

Kenkebashvili N, Elisashvili V, Wasser SP (2012) Effect of carbon, nitrogen sources, and copper concentration on the ligninolytic enzyme production by Coriolopsis gallica. J Waste Convers Bioprod Biotechnol 1:22-27

Kluczek-Turpeinen B, Holm J, Hatakka A, Kähkönen MA (2014) Impacts of aluminium, molybdenum, vanadium, zirconium, tungsten and gallium on the growth and enzyme production of ascomycetous and basidiomycetous fungi. Ann Environ Sci 8:39-47

Levin L, Melignani E, Ramos AM (2010) Effect of nitrogen sources and vitamins on ligninolytic enzyme production by some white-rot fungi. Dye decolorization by selected culture filtrates. Bioresour Technol 101:4554-4563

Lorenzo M, Moldes D, Sanromán MA (2006) Effect of heavy metals on the production of several laccase isoenzymes by Trametes versicolor and on their ability to decolourise dyes. Chemosphere 63:912-917

Madan M, Thind KS (1979) Role of trace elements on the growth and sporulation of Alternaria chartarum and A. solani. Proc Ind Nat Sci Acad 45B:628-632

Martínez MJ, Ruiz-Dueñas FJ, Guillén F, Martínez AT (1996) Purification and catalytic properties of two manganese-peroxidase isoenzymes from Pleurotus eryngii. Euro J Biochem 237:424-432

Mehta J, Jakhetia M, Choudhary S, Mirza J, Sharma D, Khatri P, Gupta P, Nair MM (2012) Impact of carbon and nitrogen sources on the Trichoderma viride (Biofungicide) and Beauveria bassiana (entomopathogenic fungi). Euro J Exp Bio 2:2061-2067

Mikiashvili N, Elisashvili V, Wasser S, Nevo E (2005) Carbon and nitrogen sources influence the ligninolytic enzyme activity of Trametes versicolor. Biotechnol Lett 27:955-959

Mtui GYS (2012) Lignocellulolytic enzymes from tropical fungi: types, substrates and applications. Sci Res Essays 7:1544-1555

Murugesan K, Kim YM, Jeon JR, Chang YS (2009) Effect of metal ions on reactive dye decolorization by laccase from Ganoderma lucidum. J Hazard Mater 168:523-529 
Perez J, Jeffries TW (1992) Roles of manganese and organic acid chelators in regulating lignin degradation and biosynthesis of peroxidases by Phanerochaete chrysosporium. Appl Environ Microbiol 58:2402-2409

Périé FH, Gold MH (1991) Manganese regulation of manganese peroxidase expression and lignin degradation by the white-rot fungus Dichomitus squalens. Appl Environ Microbiol 57:2240-2245

Prasher IB, Chauhan R (2013) Factors for the growth, ligninolytic enzymes and tartaric acid production of Grammothele fuligo. CIBTech J Biotechnol 2:65-71

Prasher IB, Chauhan R (2015) Effect of Carbon and nitrogen sources on the growth, reproduction and ligninolytic enzymes activity of Dictyoarthrinium synnematicum Somrith. Adv Zool Bot 3:24-30

Prasher IB, Chauhan R (2017) Influence of trace elements on ligninolytic enzymes activity of Dictyoarthrinium synnematicum. Int J Curr Adv Res 6:6248-6252

Prasher IB, Chandel VC, Chauhan R (2014) Effect of carbon and nitrogen sources on growth and luminescence of Panellus stipticus (Bull.) P. Karst. J Adv Bot Zool. https://doi.org/10.15297/JABZ. V1I4.08

Sankhla HC, Masih B, Mathur RL (1970) Effect of trace elements and growth regulators on Alternaria burnsii incitant of blight on Cumin. Ind Phytopath 23:533-537

Sharma VP, Sharma SR, Kumar S (2004) Physiological requirements and cultivation of Agrocybe aegerita. Mushroom Res 13:66-70

Singhal V, Rathore VS (2001) Effects of $\mathrm{Zn}^{2+}$ and $\mathrm{Cu}^{2+}$ on growth, lignin degradation and ligninolytic enzymes in Phanerochaete chrysosporium. World J Microbiol Biotechnol 17:235-240

Stajic M, Persky L, Friesem D, Hadar Y, Wasser SP, Nevo E, Vukojevic $\mathrm{J}$ (2006) Effect of different carbon and nitrogen sources on laccase and peroxidises production by selected Pleurotus species. Enzyme Microb Technol 38:65-73

Stajic M, Vukojevic J, Knezevic A, Milovanovic I (2013) Influence of trace elements on ligninolytic enzyme activity of Pleurotus ostreatus and P. pulmonarius. Bioresources 8:3027-3037

Steffen KT, Hofrichter M, Hatakka A (2002) Purification and characterization of manganese peroxidases from the litter-decomposing basidiomycetes Agrocybe praecox and Stropharia coronilla. Enzyme Microb Technol 30:550-555

Tekere M, Zvauya R, Read JS (2001) Ligninolytic enzyme production in selected sub-tropical white rot fungi under different culture conditions. J Basic Microbiol 41:115-129

Terashima Y (2013) Physiological characteristics of the trunk sap rot pathogen Fomitoporia sp. on the "Sanbu-sugi" cultivar of Cryptomeria japonica. Mycoscience 54:171-177

Tychanowicz GK, de Souza DF, Souza CGM, Kadowaki MK, Peralta RM (2006) Copper improves the production of laccase by the white-rot fungus Pleurotus pulmonarius in solid state fermentation. Braz Arch Biol Technol 49:699-704

Vaithanomsat P, Sangnam A, Boonpratuang T, Choeyklin R, Promkiamon P, Chuntranuluck S, Kreetachat T (2013) Wood degradation and optimized laccase production by resupinate white-rot fungi in Northern Thailand. Bioresources 8:6342-6360

Publisher's Note Springer Nature remains neutral with regard to jurisdictional claims in published maps and institutional affiliations. 